\title{
11. Contingent liabilities: monitoring exposures that are difficult to measure
}

\author{
Timothy C. Irwin ${ }^{1}$
}

\section{INTRODUCTION}

Contingent liabilities matter for debt sustainability because their realization can cause debt to increase sharply and suddenly. Thus, even countries with apparently sound public finances can have debt-sustainability problems if their contingent liabilities are troublesome. Indonesia and Thailand, for example, entered the Asian financial crisis of 1997-1998 with low public debt and having recently run moderate budget deficits or even surpluses, but their public finances were quickly undermined by the realization of explicit and implicit contingent liabilities (Brixi and Gooptu 2002, p. 251). Iceland and Spain had a similar experience during the global financial crisis of 2008. More generally, Bova et al. (2019, p. 381) find that the realization of contingent liabilities after the global financial crisis accounted for "as much as one-third" of the subsequent increases in public debt. And studies of the causes of the long-term growth of public debt have found that traditionally measured deficits, growth rates, and interest rates have less explanatory power than might be expected, while factors that increase debt without showing up in the traditionally measured deficit are crucial; perhaps the most important such factor is the depreciation of the local currency in the presence of foreign-currency debt, but another is the realization of contingent liabilities (Kharas and Mishra 2001; Campos et al. 2006; Jaramillo et al. 2017).

Contingent liabilities and the surprises they create cannot be eliminated. Even if a government avoids explicitly underwriting any risks, it will almost certainly underwrite some implicitly, as the risk-bearer of last resort. As someone once said of deposit insurance: there are two types of government - those that offer it and those that think they don't. ${ }^{2}$ Surprises are of course inevitable. Yet they can be amplified by the opacity of many contingent liabilities, especially the implicit ones; by inadequacies in governments' monitoring of even the explicit ones; and the tendency of governments to assume obligations in a form that does not immediately increase the reported level of public debt. As Buchheit and Gulati (2014, p. 241) write,

It is a truth universally acknowledged, that a sovereign borrower in possession of an uncomfortably large stock of debt, must be in want of camouflage. And since the commencement of the financial crisis in 2008, many sovereigns seem to have found it - in the form of contingent sovereign liabilities.

Contingent liabilities are by no means new. Livy and Suetonius write of the Roman Republic and Empire offering guarantees in contracts with military suppliers (Irwin 2007, pp. 12-13), 
and in the nineteenth century, governments around the world encouraged the building of railways by guaranteeing investors a minimum rate of return (Eichengreen 1996; Irwin 2007, pp. 14-15). The economic literature on contingent liabilities is also old, if not as ancient as the liabilities themselves. Mann (1947), for example, defended the United States (US) government's use of guarantees in the first decades of the twentieth century. Merton (1977) influentially pointed out that government guarantees have the same kind of payoffs as put options, and their costs can therefore be estimated using the techniques of option pricing. Baldwin et al. (1983) and Phaup (1985) drew attention to the failure of budgetary accounting in Canada and the US, respectively, to recognize these costs. Work by international organizations on contingent liabilities (and the broader issue of fiscal risk) took off in the 1990s and has continued apace, spurred on by the Asian and the global financial crises (e.g., Towe 1991; Irwin et al. 1997; Polackova 1998; Brixi and Schick 2002; Hemming et al. 2006; Cebotari 2008; IMF 2008, 2016; Kopits 2014).

The effect of the novel coronavirus (COVID-19) on public finances in Asia makes a review of contingent liabilities timely. The region appears, at the time of writing, in late 2020, to be weathering the pandemic better than most, but growth has slowed, and public debt has increased (see Chapter 1, this volume). Countries such as Japan and the Republic of Korea (ROK) have also responded to the pandemic by incurring new contingent liabilities. ${ }^{3}$

This chapter therefore takes a fresh look at contingent liabilities in Asia (ADB's developing members and Japan) and the ways they can be monitored. The contingent liabilities it examines are the direct liabilities of entities other than the central government that may become liabilities of the central government if the other entities become financially distressed. Those entities include subnational governments, state-owned enterprises, banks and other financial institutions, firms involved in public-private partnerships (PPPs), and any entity that benefits from an explicit government guarantee. Excluded from the analysis are certain other contingent liabilities, such as those arising from lawsuits against the government; certain direct obligations of the central government that are sometimes described as contingent liabilities, such as obligations to pay pensions (e.g., Towe 1991); and obligations that are especially difficult to value, which accountants sometimes call contingent liabilities. ${ }^{4}$

One entity's direct liabilities may become the government's contingent liabilities when the government signs a contract to guarantee them, but, as indicated above, this is not the only way. A contingent liability may arise from a letter of comfort, in which the government makes a softer but possibly still significant commitment; or from a law, such as one guaranteeing bank deposits. Alternatively, officials may imply with a series of nods and winks that the government stands behind an entity's liabilities (Buchheit and Gulati 2014), or the extent of the government's involvement in the entity's activities may by itself suggest that it will do so, as in the case of many state-owned enterprises and the "government-sponsored" entities Fannie Mae and Freddie Mac (Phaup 2009; Frame et al. 2015). Finally, the government may sometimes be expected to conclude, irrespective of any of its prior words or actions, that the costs of letting the entity default on its liabilities are greater than the costs of bailing it out — as with the US government's 2009 rescue of General Motors (Goolsbee and Krueger 2015).

As the last example illustrates, some entities' liabilities may become the government's liabilities only during an economy-wide crisis: in better times, the US government might have allowed General Motors to fail. More generally, because many contingent liabilities do not arise from clear-cut laws or contracts, whether the government would assume the 
liabilities may be unknown. National governments seldom allow subnational governments or state-owned enterprises to default on their debts, but occasionally they do, as in the People's Republic of China (PRC), where some state-owned enterprises have defaulted on their debts, and in the US, where some subnational governments have done so. Thus, many of the liabilities discussed in this chapter are best described as possible contingent liabilities.

The chapter first examines the available evidence on the gross magnitude of the possible contingent liabilities of the central governments of the region's five largest economies: the PRC, India, Indonesia, Japan and the ROK. Together, these countries account for 92 percent of the region's public debt and no doubt a large share of its contingent liabilities. ${ }^{5}$ The analysis focuses on data in cross-country databases because these data tend to be at least partly standardized and thus more nearly comparable between countries, and because they are what are most suitable to the international monitoring of debt sustainability. Nevertheless, some attention is paid to country-specific information.

The chapter aims to answer both a first-order question about the size of the possible contingent liabilities in the five countries and a second-order question about the availability of cross-country information on the issue. On the second-order question, it finds that, even for these large, globally important, middle- or high-income countries, the cross-country databases have major gaps. To take a striking example, one of the databases provides for information on governments' explicit contingent liabilities, including government guarantees of debt, but each value is missing for each of the five countries. In other areas, information is available for some countries but not others. Notably scarce are data on India and, especially, the PRC. Given the gaps in the data for these five large countries, it seems safe to assume that the region's smaller, poorer countries also have major gaps in their data. Nevertheless, some of the databases were developed only in the last few years, so there is room for optimism.

The answer to the first-order question is necessarily limited by the gaps in the data, but there are clearly large differences in the gross size of the different types of possible contingent liabilities among the five countries. For example, the Indonesian government's possible contingent liabilities related to subnational governments appear to amount to about 0.3 percent of GDP, while those of its Japanese counterpart are two orders of magnitude larger. All the countries have significant possible contingent liabilities related to state-owned enterprises, but those of Indonesia are, again, the smallest, at 6-12 percent of GDP (depending on the data source), and those of the PRC the largest, with some estimates (not in the databases) putting them at more than 100 percent of GDP. Possible contingent liabilities arising from PPPs in infrastructure seem relatively small in the countries for which data are available, ranging from less than 1 percent of GDP in the PRC to just over 5 percent in India. Public and private banks are generally the largest source of contingent liabilities, though the data on them are far from complete.

The chapter ends by sketching three strategies for monitoring possible contingent liabilities. It does not consider the details of monitoring, which necessarily differ from one kind of contingent liability to another, but instead looks at some high-level aspects of measurement and control that are common to the monitoring of all the possible contingent liabilities considered. The first strategy is to monitor the gross amount of contingent liabilities, as many Asian governments do with explicit government guarantees. A second strategy, seemingly less popular in Asia, addresses an obvious weakness in the first strategy: that it takes no account of the probabilities that contingent liabilities will be realized. It is to monitor some probability-dependent measure such as the contingent liabilities' market value or expected cost. The third strategy is, 
essentially, to redefine the government's debt to treat many would-be contingent liabilities as ordinary liabilities and monitor this broader measure of debt.

\section{CONTINGENT LIABILITIES IN ASIA'S FIVE LARGEST ECONOMIES}

The first task in monitoring contingent liabilities is to determine their gross amount. To do this, we need to measure the size of the liabilities explicitly guaranteed by central government, as well as those of entities that are likely to benefit from some degree of implicit government guarantee, including subnational governments; state-owned enterprises, public banks, and other public corporations; private companies involved in PPPs; and private banks and other private financial corporations. How, then, should the size of these liabilities be measured?

The first question is which obligations to count (Dippelsman et al. 2012; Irwin 2015). A natural approach is to count only loans and debt securities (traditionally defined debt). But accountants and statisticians typically aim to record a wider range of liabilities, including, for example, accounts payable and the obligations associated with pensions. A second option is to count all these obligations other than equity claims (nonequity liabilities). A third option is to count only what statisticians define as debt instruments, which includes all nonequity liabilities except, curiously, those arising from financial derivatives; see the System of National Accounts 2008 (European Commission et al. 2009, paragraph 26.103).

Another question is how to value the chosen set of obligations. Traditionally defined debts are often measured at their face value, but since loans can be made at a concessional interest rate, and bonds can be issued at a premium or discount to their face value, this method is rather arbitrary (Irwin 2019). Traded debt securities are often measured at their market value, which is sometimes useful, but at other times has consequences that can seem perverse: the market value of a debt falls in value as the debtor's creditworthiness diminishes, so the gross amount of a government's contingent liabilities could decline as the probability of their realization increased. Debts are also sometimes measured at their amortized cost (the amount of money raised at the time of borrowing reduced by repayments and the amortization of any issuance premium or discount); but this method, too, has elements of the arbitrary and perverse. The measurements presented below probably contain a mix of these valuation methods, and often it is unclear exactly which are used.

\subsection{Explicit Debt Guarantees}

Explicit government guarantees of the debts of other entities tend to be closely monitored, sometimes by the government's debt manager (see Chapter 14, this volume). Many governments disclose them. The Government of India, Ministry of Finance (2020a, p. 25), to take just one example, states that the stock of debt guaranteed on 31 March 2019 amounted to 2.35 percent of GDP.

But data like these do not appear to be commonly compiled in a cross-country database. There is space in the Government Finance Statistics Database of the International Monetary Fund (IMF) for the value of "explicit contingent liabilities" and for the part thereof created by "publicly guaranteed debt"; but values for the PRC, India, Indonesia, Japan, and the ROK are all missing. ${ }^{6}$ 
Buchheit and Gulati (2014, p. 244) succeed in getting information on 885 government-guaranteed bonds issued in 1965-2013, but their sources are not helpful in our context. They are not freely available and, in the authors' words, the bonds in their dataset "probably" constitute "both a small and biased ... subset of the universe of sovereign guaranteed bonds". And even a complete database of government-guaranteed bonds would tell us nothing about government-guaranteed loans, which in most developing countries are more important.

\subsection{Subnational Governments}

Let us look, then, at the size of various entities' liabilities that might be guaranteed, implicitly or explicitly by the central government, starting with those of subnational governments. Following the terminology and conceptual framework of national accounts and government-finance statistics (e.g., IMF 2014, Ch. 2), we take subnational governments to be the noncommercial (nonmarket) parts of local and state governments.

The IMF's Government Finance Statistics Database allows for detailed, standardized information on government finances, including those of subnational governments. The data are presented according to the framework set out in IMF (2014), which in turn is based on the System of National Accounts 2008. In principle, the database allows a choice among the three possible sets of liabilities (traditionally defined debt, debt instruments, and nonequity liabilities). Moreover, the data on liabilities can in principle be reconciled with data on deficits.

Table 11.1 gives the database's information on nonequity liabilities. There are no data at all on subnational liabilities in the PRC or India. Nevertheless, the available data imply that possible contingent liabilities related to subnational government are very small in Indonesia, at less than 0.5 percent of GDP; moderate in the ROK, at about 3 percent of GDP; and rather large in Japan, at about 33 percent of GDP.

Table $11.1 \quad$ Liabilities of subnational government, 2018 (\% of GDP)

\begin{tabular}{lrr}
\hline Country & $\begin{array}{r}\text { Local } \\
\text { Government }\end{array}$ & State Government \\
\hline PRC & $\ldots$ & n.a. \\
India & $\ldots$ & $\ldots$ \\
Indonesia & 0.17 & 0.15 \\
Japan & 32.63 & n.a. \\
ROK & 3.17 & n.a. \\
\hline
\end{tabular}

Notes:

GDP = gross domestic product; PRC = People's Republic of China; ROK = Republic of Korea.

“..." means that the values are missing and "n.a." means that they are not applicable (because the country has no states).

Source: IMF. Government Finance Statistics Database. Washington, DC. https://data.imf.org/?sk=a0867067-d23c -4ebc-ad23-d3b015045405. Data were downloaded on 16 September 2020 by going to the Archive tab; then "Query or Download Data", choosing the 2019 "Vintage Annual", and then performing a "Query" on "Integrated Balance Sheet (Stock Positions and Flows in Assets and Liabilities)".

The IMF's Global Debt Database provides a different perspective and adds information for India (Table 11.2). ${ }^{7}$ This database is much less detailed than the Government Finance Statistics Database, but it does report both the debt of central government and the debt of general gov- 
ernment, the difference between them being, with one possible exception mentioned below, the debt of subnational government. The database aims to include all debt instruments (Mbaye et al. 2018), but sometimes has to settle for traditionally defined debt. In any case, for India, the database implies possible contingent liabilities associated with subnational government of about 24 percent of GDP. For Indonesia and the ROK, the values are similar to those from the Government Finance Statistics Database. The small differences might reflect differences in included liabilities or valuation methods, or the elimination upon consolidation of the claims internal to general government, such as debts owed by local governments to the central government. In the presence of such claims, the analysis of possible contingent liabilities should focus on the implied figure, to avoid a kind of double counting. Such factors might also explain the larger difference in the estimate for Japan, but the figure for the liabilities for Japan's central government may exclude liabilities related to social-security funds, as suggested by data for Japan in the Government Finance Statistics Database.

Table 11.2 Implied debt of subnational government, 2018 (\% of GDP)

\begin{tabular}{lrrr}
\hline Country & $\begin{array}{r}\text { Debt of Central } \\
\text { Government }\end{array}$ & $\begin{array}{r}\text { Debt of General } \\
\text { Government }\end{array}$ & $\begin{array}{r}\text { Implied Debt of Subnational } \\
\text { Government }\end{array}$ \\
\hline PRC & $\ldots$ & 50.6 & $\ldots$ \\
India & 43.9 & 68.1 & 24.2 \\
Indonesia & 29.8 & 30.1 & 0.3 \\
Japan $^{\mathrm{a}}$ & 198.4 & 237.1 & 38.7 \\
ROK $^{\mathrm{b}}$ & 37.7 & 40.1 & 2.4 \\
\hline
\end{tabular}

Notes:

$\ldots=$ data not available; GDP $=$ gross domestic product; $\mathrm{PRC}=$ People's Republic of China; ROK $=$ Republic of Korea.

${ }^{\text {a }}$ For Japan, the debt of central government may exclude the liabilities of social-security funds, so the implied liabilities of subnational government may be overstated.

${ }^{\mathrm{b}}$ Data for the ROK are for 2017.

Source: Global Debt Database. https://www.imf.org/-/media/Files/Publications/WP/2018/datasets/wp18111.ashx (accessed 5 September 2020).

Neither database offers an estimate of the liabilities of local government in the PRC. The Global Debt Database does, however, provide an estimate of the debt of general government and thus an upper bound on the debt of local governments. Chapter 6 in this volume offers an estimate for 2019 of 21 percent of GDP.

\subsection{Public Corporations}

Public corporations are businesses that are controlled by units of general government and operate at least somewhat commercially. Statisticians have developed tests for determining whether a government-controlled business is sufficiently commercial to be deemed a public corporation and thus not part of general government, but the dividing line tends to be blurry or, if made precise, somewhat arbitrary. In practice, the great majority of government-controlled businesses in the region are probably treated in the databases as being outside general government. In line with the distinction in macroeconomic statistics between financial and nonfinancial corporations, public corporations are conventionally divided into financial public 
corporations (public banks and other government-controlled financial institutions) and nonfinancial public corporations (state-owned enterprises, municipal enterprises, and the like). The central bank is a financial public corporation, though sui generis.

Table 11.3 shows estimates of the liabilities of nonfinancial public corporations from three sources: a recent issue of the IMF's Fiscal Monitor (IMF 2020); an IMF database of public-sector balance sheets, which, like the Government Finance Statistics Database, classifies total liabilities into components; and the World Bank's Quarterly Public Sector Debt Database, which, unlike the other two databases, has data for $2019 .{ }^{8}$ The estimates in the Fiscal Monitor for Indonesia, Japan, and the ROK appear to have been taken from the Public Sector Balance Sheet Database (one of its stated sources). The estimates from the Quarterly Public Sector Debt Database are lower for the two countries for which they are available, perhaps because of the passage of time or the counting of a narrower range of liabilities, or possibly differences in methods of valuation or the set of businesses included in the calculation.

Table 11.3 Liabilities of nonfinancial public corporations (\% of GDP)

\begin{tabular}{lrrr}
\hline Country & Fiscal Monitor & PSBS Database & QPSD Database \\
\cline { 2 - 4 } & Debt & Nonequity Liabilities & Debt \\
\cline { 2 - 4 } & $\mathbf{2 0 1 6 - 2 0 1 8}$ & $\mathbf{2 0 1 6}$ & $\mathbf{2 0 1 9}$ \\
\hline PRC & 46.89 & $\ldots$ & $\ldots$ \\
India & $\ldots$ & 22.35 & $\ldots$ \\
Indonesia & 11.89 & 11.89 & 6.31 \\
Japan & 17.20 & 17.20 & 15.89 \\
ROK & 23.54 & 23.54 & $\ldots$ \\
\hline
\end{tabular}

Notes:

$\ldots=$ data not available; GDP = gross domestic product; PRC = People's Republic of China; PSBS = Public Sector Balance Sheet; QPSD = Quarterly Public Sector Debt Database; ROK = Republic of Korea.

Sources: IMF (2020, Figure 3.18); IMF. Public Sector Balance Sheet Database. Washington, DC: https://data.imf .org/?sk=82A91796-0326-4629-9E1D-C7F8422B8BE6; and World Bank. QPSD: Quarterly Public Sector Debt.

Table C1. Washington, DC: https://datatopics.worldbank.org/debt/qpsd.

The available data suggest that the liabilities of nonfinancial public corporations are significant in all five countries and especially large in the PRC. They are smallest in Indonesia, at about 6-12 percent of GDP (depending on the data source); somewhat larger in Japan, at about 16-17 percent of GDP; and somewhat larger still in the ROK, at about 24 percent of GDP. For the PRC, the only estimate in the cross-country databases is from the Fiscal Monitor, which reports "debt" of "state-owned enterprises" of 46.9 percent of GDP. Ferrarini and Hinojales (2018, p. 5), however, identify debt of state-owned enterprises in the PRC of 50.9 percent of GDP in 2016 and note that their "sample falls significantly short of total SOE debt"; they prefer an estimate due to Moody's of 115 percent of GDP. Lee and Naqvi (2020, pp. 192-3) report estimates of $\$ 15.1$ trillion-\$15.3 trillion in 2016, or about 135 percent of GDP.

The liabilities of financial public corporations are large in all countries for which data are available, especially in India and Japan. Table 11.4 reports three measures of the liabilities. The measures in the first two columns are from the IMF's Public Sector Balance Sheet Database, with the first column showing the traditionally defined debt of public financial corporations, including, it seems, each country's central bank; and the second column showing estimates of 
their nonequity liabilities, including, among other things, the deposits held in public banks. The third column reports data from the World Bank's Quarterly Public Sector Debt Database (whether the estimates in this column include the central bank is unclear). For Japan, nonequity liabilities according to the Public Sector Balance Sheet Database are about 193 percent of GDP. Liabilities are also large in India and may not be as comprehensively defined. Liabilities in the ROK are also large, at a little more than 70 percent of GDP. They are rather lower in Indonesia, at about 34 percent of GDP.

Table 11.4 Liabilities of financial public corporations (\% of GDP)

\begin{tabular}{lrrr}
\hline Country & $\begin{array}{r}\text { PSBS Loans and Debt } \\
\text { Securities } \\
\text { 2016 }\end{array}$ & PSBS Nonequity Liabilities & QPSD Debt \\
& $\mathbf{2 0 1 6}$ & \\
\hline PRC & $\ldots$ & $\ldots$ & $\ldots$ \\
India & $\ldots$ & 73.14 & $\ldots$ \\
Indonesia & 3.44 & 33.77 & 26.42 \\
Japan & 48.61 & 193.30 & 47.96 \\
ROK & 37.28 & 67.58 & $\ldots$ \\
\hline
\end{tabular}

Notes:

$\ldots=$ data not available; GDP = gross domestic product; PRC = People's Republic of China; PSBS = Public Sector Balance Sheet; QPSD = Quarterly Public Sector Debt Database; ROK = Republic of Korea.

Sources: IMF. PSBS. Washington, DC: https://data.imf.org/?sk=82A91796-0326-4629-9E1D-C7F8422B8BE6; World Bank. QPSD: Quarterly Public Sector Debt. Table C1. Washington, DC: https://datatopics.worldbank.org/ debt/qpsd.

\subsection{Consolidated Liabilities of the Public Sector}

Lending by one part of the public sector to another means that, for the purpose of measuring the possible contingent liabilities of the central government, the liabilities of public corporations cannot simply be added to those of the central government. Among other things, the central government may borrow from public banks, while state-owned enterprises may borrow from the central government. We can get a better sense of the incremental possible contingent liabilities created by public corporations by comparing the debt of the public sector with that of the central government.

Table 11.5 does this for traditionally defined debt (loans and debt securities), for which results are probably most nearly comparable among countries. In Indonesia, the data suggest that public corporations create a relatively small possible contingent liability, at about 3 percent of GDP. In the ROK, the additional traditionally defined debt is large, at about 54 percent of GDP. Most striking are the data for Japan, which imply that the traditionally defined debt of the public sector is significantly smaller than that of the central government, presumably because of the central bank's ownership of government bonds. 
Table 11.5 Loans and debt securities of central government and the public sector, 2016 $(\%$ of $G D P)$

\begin{tabular}{lrrr}
\hline Country & Central Government & Public Sector & Difference \\
\hline PRC & $\ldots$ & $\ldots$ & $\ldots$ \\
India & $\ldots$ & $\ldots$ & $\ldots$ \\
Indonesia & 28.5 & 31.7 & 3.2 \\
Japan & 192.7 & 140.7 & -52.0 \\
ROK & 37.2 & 91.1 & 53.9 \\
\hline
\end{tabular}

Notes:

$\ldots$ = data not available; GDP = gross domestic product; $\mathrm{PRC}=$ People's Republic of China; ROK $=$ Republic of Korea.

Source: IMF. PSBS. Washington, DC: https://data.imf.org/?sk=82A91796-0326-4629-9E1D-C7F8422B8BE6.

If we consider all nonequity liabilities, the picture changes somewhat (Table 11.6), though inconsistencies in data make country comparisons riskier. The nonequity liabilities of the public sector are, for all three countries for which data are available, much larger than the nonequity liabilities of the central government. For Japan, the explanation is partly liabilities in the form of the "currency and deposits" of the public sector, which amount to about 113 percent of GDP.

Table 11.6 Nonequity liabilities of central government and the public sector, $2016(\%$ of GDP)

\begin{tabular}{lrrr}
\hline Country & Central Government & Public Sector & Difference \\
\hline PRC & $\ldots$ & $\ldots$ & $\ldots$ \\
India & $\ldots$ & 124.98 & $\ldots$ \\
Indonesia & 31.30 & 67.13 & 35.83 \\
Japan & 264.55 & 313.87 & 49.32 \\
ROK & 89.61 & 173.87 & 84.26 \\
\hline
\end{tabular}

Notes:

$\ldots=$ data not available; GDP $=$ gross domestic product; $\mathrm{PRC}=$ People's Republic of China; ROK $=$ Republic of Korea.

Source: IMF. PSBS. Washington, DC: https://data.imf.org/?sk=82A91796-0326-4629-9E1D-C7F8422B8BE6.

\subsection{Public-Private Partnerships}

The liabilities of private companies in PPPs are another source of possible contingent liabilities for the government. Accountants and statisticians sometimes treat PPPs as creating liabilities (as well as assets) for the government (see IPSAS 32 in IPSAS Board 2018b; IMF 2014, pp. 324-7). Thus, some liabilities related to PPPs could already be included in the debt of the public sector reported in Table 11.5. But this approach is not commonly applied, so it is worth looking at available information on contingent liabilities related specifically to PPPs. 
Rough estimates can be extracted from the World Bank's Private Participation in Infrastructure Database. ${ }^{9}$ The database aims to register infrastructure PPPs in low- and middle-income countries and thus excludes those in Japan and the ROK. For each identified project, the database includes the amount and year of investment, the percentage of the investment that is privately financed, and the length of the PPP contract. We can get an estimate of a government's total possible contingent liabilities at the end of 2019 if we assume that the government's possible contingent liability in relation to each project is initially equal to the full amount of private investment and then declines in a straight line until it reaches zero at the end of the contract. ${ }^{10}$ Estimated in this way, the possible contingent liabilities are 0.7 percent of GDP in the PRC, 3.4 percent of GDP in Indonesia, and 5.3 percent of GDP in India.

\subsection{Banks}

In examining the liabilities of financial public corporations, we have already considered some of the possible contingent liabilities associated with banks and other financial institutions. But we also need to consider possible contingent liabilities related to private banks and financial institutions. There do not appear to be any public databases that report the liabilities of financial corporations and distinguish public corporations from private corporations. The IMF's Financial Soundness Indicators Database does, however, provide information on the liabilities of deposit-taking corporations, whether public or private, and for some countries the liabilities of other financial corporations (Table 11.7). These liabilities are particularly large in the ROK, at well over 100 percent of GDP. Data on Japan and the PRC are unavailable, though.

Table 11.7 Nonequity liabilities of financial corporations, 2019 (\% of GDP)

\begin{tabular}{lrr}
\hline Country & $\begin{array}{r}\text { Deposit-Taking Financial } \\
\text { Corporations }\end{array}$ & Other Financial Corporations \\
\hline PRC & $\ldots$ & $\ldots$ \\
India & 76.6 & 16.2 \\
Indonesia & 44.8 & $\ldots$ \\
Japan & $\ldots$ & $\ldots$ \\
ROK & 118.4 & 152.7 \\
\hline
\end{tabular}

Notes:

$\ldots=$ data not available; GDP $=$ gross domestic product; $\mathrm{PRC}=$ People's Republic of China; ROK $=$ Republic of Korea.

Sources: For financial corporations: IMF. Financial Soundness Indicators Database: https://data.imf.org/?sk= 51B096FA-2CD2-40C2-8D09-0699CC1764DA\&sId=1411569045760; estimates of GDP at the end of 2019: IMF. World Economic Outlook. October 2019 edn: https://www.imf.org/en/Publications/WEO/weo-database/2019/ October.

\section{MONITORING CONTINGENT LIABILITIES}

Consider now some ways of measuring contingent liabilities for the purposes of monitoring. 


\subsection{Gross Amounts}

The simplest way is to focus, like the previous section of this chapter, on the gross amount of the contingent liabilities. The disclosure of such measurements is required by many accounting standards (e.g., IPSAS 19 in IPSAS Board 2018a) and is encouraged by the main guidelines for preparing statistics on debt and government finances generally (IMF 2011, pp. 47-51; and IMF 2014, pp. 76-7). Many examples of the reporting of this kind of measurement can be found in the region, in various kinds of government documents such as the following:

- The Government of Bhutan's financial statements (Government of Bhutan, Ministry of Finance 2019, Table 22);

- The Government of India's statement of guarantees (Government of India, Ministry of Finance 2020b, pp. 50-52; 2020a, p. 25);

- The Government of the Philippines' statement of fiscal risks (Government of the Philippines, Development Budget Coordination Committee 2019, sections VII-VIII);

- Thailand's Public Debt Management Office's reports on public debt (see Thai Public Debt Management Office 2020 and Public Debt Data ${ }^{11}$ ).

The gross amount of contingent liabilities can be made the subject of a fiscal rule. In Armenia, for example, the stock of guarantees has been legally limited as a percentage of GDP (World Bank 2013, p. 25). In the Philippines, it is the dollar value of the stock of guarantees of foreign-currency borrowing that has been limited (World Bank 2019, p. 126), and in India it is the annual issuance of guarantees (Government of India, Ministry of Finance 2010). It is also possible to limit the sum of guaranteed and direct debt.

The same approach can also be used to monitor possible contingent liabilities that arise from implicit guarantees, which are often much larger than the contingent liabilities that arise from explicit guarantees. For example, as noted above, the Government of India has disclosed explicit guarantees of 2.35 percent of GDP, but as Tables 11.2, 11.3, 11.4, and 11.7 show, its possible contingent liabilities are much larger. Governments are justifiably wary of discussing implicit contingent liabilities for fear of making them firmer and encouraging moral hazard. But governments can monitor this information privately, and they can publish information on the liabilities without any implication that the liabilities are government guaranteed.

Monitoring the gross amount of contingent liabilities is simple; no estimation is required, only the use of information the government already has or can obtain. But it says nothing about the likelihood of the possible contingent liabilities' being realized. This limitation does not make it useless though. Governments sensibly monitor gross debt even though it is used to finance investments and pay for government services that are expected directly or indirectly to generate revenue that can be used to repay the debt - in this case, as with contingent liabilities, whether the government will ultimately lose money depends on the balance between the debt and the revenue the debt generates. Nevertheless, just as governments estimate their net as well as their gross debt, they sometimes estimate the probability that contingent liabilities will be realized. 


\subsection{Probability-Dependent Measures}

At least three types of probability-dependent measure can be estimated. The first is the contingent liability's expected value. In the simple case in which the contingent liability is either fully realized or not, the expected payment is the gross amount of the contingent liability multiplied by the probability that it will be realized. More often, the contingent liability may be partially realized, and the expected value is the probability-weighted sum of the possibly realized amounts. Since the possible payments occur in the future, it is natural to discount them to the present by, say, the government's borrowing rate. The US federal government takes this approach to many types of guarantees in its budgets. Instead of recording the cost of guarantees when they are called, the budgets record in the year in which guarantees are issued an estimate of the discounted present value of the expected cost of future payments less receipts. This means that guarantees do not seem like a free good to policy makers and, at least to a first approximation, budgetary accounting does not distort the choice between guarantees and other instruments such as spending and lending (Phaup 1993; Schick 2002).

The second type of measurement modifies the first approach to take account of the nature of the risks created by guarantees. In particular, guarantees that tend to be called during recessions, when the government's revenue is low, are arguably more costly to grant than guarantees that are called at random or when the economy is booming. This effect is captured by the market value of guarantees, and there is thus a case for estimating market values (Lucas and Phaup 2008; Lucas 2010). The Government of New South Wales in Australia sets guarantee fees in a way that approximates their market value (New South Wales Treasury 2014). And the Chilean and Peruvian governments have estimated the market value of revenue guarantees granted to companies in toll-road concessions (see Chilean Budget Department 2007; and Peruvian Ministry of Economics and Finance 2007).

The third possibility is to measure losses in statistically defined bad scenarios. The Chilean government, for example, publishes projections of the 95th percentile of the estimated distribution of its annual payments for the revenue guarantees for toll-road concessions. The Colombian government takes a similar approach for its loan guarantees (see Colombian Ministry of Finance and Public Credit 2015; and, for background, Bachmair 2016; and IMF 2017).

The main disadvantages of these probability-dependent measures are that they are difficult to estimate and that the resulting measurements can be unreliable. Moreover, even if they can be made precise, some are volatile, which makes them an unsuitable basis for binding fiscal targets.

\subsection{Comprehensive Measures of Debt}

This prompts consideration of a third strategy, which is to prepare fiscal accounts that are sufficiently comprehensive as to treat many would-be contingent liabilities as ordinary liabilities. Fiscal accounts can be made more comprehensive in two ways: (1) more of a government's obligations can be treated as liabilities that must be recorded on its balance sheet, and (2) the perimeter of the government entity whose accounts are being measured can be broadened to include more public and quasi-public bodies and thus their liabilities. Many steps in these two directions are required or encouraged by accounting and statistical norms. Though few gov- 
ernments currently follow all these norms, many have taken some of the recommended steps, and a few publish fiscal accounts that are comprehensive enough to treat as ordinary liabilities many of the obligations described above as possible contingent liabilities.

Consider first extensions of the government entity's perimeter. Although fiscal analysis can track the debt of the government as a legal entity, economists frequently aim to monitor the debt of general government. When this is done, contingent liabilities related to the debts of government agencies and subnational governments become ordinary liabilities in the data. A notable example of this approach is the measurement and control of government debt in the European Union, where fiscal rules apply to general government (Eurostat 2019, Ch. 1). Still left out are possible contingent liabilities related to public corporations. They can be incorporated by measuring the accounts of the public sector, as in Tables 11.5 and 11.6; in the fiscal statistics published by the Australian Bureau of Statistics ${ }^{12}$ and the UK Office for National Statistics (2020); and in the Whole of Government Accounts published by the UK Treasury (2019). The Australian and New Zealand governments publish financial statements that incorporate all the entities they are deemed to control, which excludes subnational governments, but includes state-owned enterprises and public banks (Australian Government 2019; New Zealand Treasury 2019). Debt-sustainability analysis can be done for the public sector as well as for narrower definitions of government so long as both the debt and the primary surplus are measured for the same institutional entity.

Second, broader definitions of the government's assets and liabilities can also turn some would-be contingent liabilities into ordinary liabilities. In fiscal statistics, one-off guarantees are not treated as creating a liability that must be shown on the balance sheet, but a portfolio of "standardized" guarantees creates an ordinary liability recorded at the "present value of the expected calls ... net of any recoveries" (International Monetary Fund 2011, para. 2.136). In the United Kingdom (UK), the Office for National Statistics has indicated that some of the guarantees introduced by the UK government after the COVID-19 pandemic will be recorded in this way (UK Office for National Statistics 2020). Many accounting standards require a similar on-balance-sheet treatment of any contingent liability that is more likely to be realized than not (see IPSAS 19 in IPSAS Board 2018a), and some generally require guarantees to be recorded at their market value, even if they probably will not be called. ${ }^{13}$ At other times, accounting rules may effectively treat the entire gross amount of the would-be contingent liability as an ordinary liability. For example, the Philippines Power Sector Assets \& Liabilities Management Corporation $(2020$, pp. 14, 28) recognizes on its balance sheet a liability of this kind related to long-term power-purchase agreements with private power companies (as well as a corresponding asset).

The strategy of defining debt comprehensively is attractive in that it facilitates the monitoring of a broad range of would-be contingent liabilities, presenting their amounts not in supplementary tables but in a potentially prominent measure of public debt. If the comprehensive measure of debt is subject to a fiscal rule or target, the control of debt is automatically control of many would-be contingent liabilities. The strategy is similar in some respects to the first strategy - monitoring the gross size of contingent liabilities - but the production of comprehensive accounts has some further advantages: (1) it ensures consolidation (i.e., the elimination of intragovernmental flows and claims); (2) it allows for the articulation of data on fiscal stocks with data on fiscal flows and thus for a measure of the budget deficit that corresponds to the measure of debt that combines direct and otherwise-contingent liabilities; and 
(3) it shows the assets that are associated with the (otherwise-contingent) liabilities, and thus gives an indication, albeit imperfect, of the severity of the problems they create.

Yet the strategy is by no means a panacea. It could not be applied to the implicit contingent liabilities created by private banks and other financial institutions without a rather fundamental change in the nature of fiscal accounts. Nor could it reasonably incorporate contingent liabilities related to explicit guarantees given to ordinary private firms or households. It might also be argued that consolidation in the accounts makes it harder for the government to disavow any implicit liabilities, though the New Zealand government seems to have required creditors to bear losses in the insolvency of two of its state-owned enterprises despite consolidating the enterprises in its accounts (New Zealand Minister of Finance 2001; New Zealand Treasury 2016). And to the extent that the government might let some public bodies fail without standing behind their liabilities, the strategy is not a substitute for measuring expected costs or market values.

\section{CONCLUSION}

The evidence surveyed here suggests that in Asia's five largest economies - the PRC, India, Indonesia, Japan, and the ROK - the central government's possible contingent liabilities arising from the liabilities of entities that may benefit from explicit or implicit guarantees are generally large - in some countries, much larger than the government's direct liabilities. Indonesia is something of an exception, having relatively small possible contingent liabilities, at least related to subnational governments and state-owned enterprises. Among the types of contingent liabilities considered here, those related to PPPs appear relatively small, with those related to state-owned enterprises and, especially, banks and other financial institutions being much larger.

Perhaps the main conclusion of the attempt to assess contingent liabilities in these countries, however, is that cross-country data on the gross magnitude of contingent liabilities - even in the region's large middle- and high-income countries - are patchy and often out of date. Although country-specific information is sometimes better, the gaps in cross-country data frustrate international monitoring of debt sustainability. Better data would facilitate three types of monitoring of contingent liabilities: (1) tracking the gross magnitude of the liabilities of entities whose liabilities may be implicitly or explicitly government guaranteed; (2) estimating the contingent liabilities' expected costs and other probability-dependent measures; and (3) constructing broad measures of public debt that effectively treat many contingent liabilities as direct liabilities.

\section{NOTES}

1. The views expressed therein are those of the authors and do not necessarily reflect the views and policies of $\mathrm{ADB}$, its Board of Governors or the governments they represent. For comments and other assistance, thanks are due to Benno Ferrarini, Marcelo Giugale, Luis de la Plaza, Juan Pradelli, Reza Vaez-Zadeh, and other participants at the authors' virtual workshop.

2. I recall hearing this said many years ago but do not recall the source.

3. See Annex Table 1.1 of IMF (2020) and Chapter 2 in this volume.

4. See part (b) (ii) of the definition of "contingent liability" in International Public Sector Accounting Standards (IPSAS) Board (2018c, 2410). 
5. The PRC, India, Indonesia, Japan, and the ROK are the five largest countries in Asia by GDP at market prices in 2018 according to ADB (2019, Table 2.2.2). Debt is defined here as the gross debt of general government at the end of 2019 according to the IMF's World Economic Outlook Database, October 2019 edn. Accessed at: https://www.imf.org/en/Publications/WEO/weo -database/2019/October.

6. See the GFS 2019 tables in Country and World Tables in IMF Government Finance Statistics. Accessed at: https://data.imf.org/?sk=a0867067-d23c-4ebc-ad23-d3b015045405.

7. IMF. https://www.imf.org/-/media/Files/Publications/WP/2018/datasets/wp18111.ashx (accessed 5 September 2020).

8. See IMF. Public Sector Balance Sheet Database. https://data.imf.org/?sk=82A91796-0326 -4629-9E1D-C7F8422B8BE6 (accessed 5 September 2020); World Bank. QPSD: Quarterly Public Sector Debt. https://datatopics.worldbank.org/debt/qpsd (accessed 5 September 2020). Another possible source is the Global Debt Database, which has some estimates of the debt of the nonfinancial public sector (i.e., general government and nonfinancial public corporations), but for the five countries considered in this chapter the estimates of the debt of the nonfinancial public sector are either missing or identical to the estimate of the debt of general government, which is presumably an error.

9. World Bank. Private Participation in Infrastructure (PPI) Database. https://ppi.worldbank.org/en/ ppi (accessed 4 September 2020).

10. The sectors included in the calculation are energy, transport, and water and sewerage (excluded are telecommunications and solid waste). The types of projects included are brownfield and greenfield (excluded are divestitures and management and lease contracts). Projects of all statuses except canceled are included. Cross-border projects are excluded. The US dollar figures in the database are expressed as percentages of GDP using estimates of the countries' 2019 GDP in current US dollars in the IMF's World Economic Outlook Database, October 2019 edn. Accessed at: https://www.imf .org/en/Publications/WEO/weo-database/2019/October.

11. Public Debt Management Office. Public Debt Data. http://www.pdmo.go.th/en/public-debt/debt -outstanding.

12. Australian Bureau of Statistics. Government Finance Statistics, Annual. https://www.abs.gov.au/ ausstats/abs@.nsf/mf/5512.0.

13. See Financial Accounting Standards Board. Summary of Interpretation No. 45. Guarantor's Accounting and Disclosure Requirements for Guarantees, Including Indirect Guarantees of Indebtedness of Others-An Interpretation of FASB Statements No. 5, 57, and 107 and Rescission of FASB Interpretation No. 34. Accessed at: https://www.fasb.org/summary/finsum45.shtml.

\section{REFERENCES}

Asian Development Bank (ADB). 2019. Key Indicators for Asia and the Pacific 2019. Manila.

Australian Government. 2019. Consolidated Financial Statements for the Year Ended 30 June 2019. Accessed at: https://www.finance.gov.au/sites/default/files/2019-12/consolidated-financial -statements-201819.pdf.

Bachmair, F.F. 2016. Contingent Liabilities Risk Management: A Credit Risk Analysis Framework for Sovereign Guarantees and On-Lending. Country Experiences from Colombia, Indonesia, Sweden, and Turkey. Policy Research Working Paper. 7538. Washington, DC: World Bank.

Baldwin, C.Y., D.R. Lessard and S.P. Mason. 1983. Budgetary Time Bombs: Controlling Government Loan Guarantees. Canadian Public Policy. 9(3), pp. 338-46.

Bova, E., M. Ruiz-Arranz, F. Toscani and H.E. Ture. 2019. The Impact of Contingent Liability Realizations on Public Finances. International Tax and Public Finance. 26, pp. 381-417.

Brixi, H.P. and S. Gooptu. 2002. Dealing with Contingent Liabilities in Indonesia and Thailand. In H.P. Brixi and A. Schick (eds), Government at Risk: Contingent Liabilities and Fiscal Risk. Washington, DC: World Bank and Oxford University Press. pp. 251-67.

Brixi, H.P. and A. Schick (eds) 2002. Government at Risk: Contingent Liabilities and Fiscal Risk. Washington, DC: World Bank and Oxford University Press. 
Buchheit, L.C. and G.M. Gulati. 2014. Sovereign Contingent Liabilities. In L. Buchheit and R. Lastra (eds), Sovereign Debt Management. Oxford: Oxford University Press. pp. 241-54.

Campos, C.F.S., D. Jaimovich and U. Panizza. 2006. The Unexplained Part of Public Debt. Emerging Markets Review. 7(3), pp. 228-43.

Cebotari, A. 2008. Contingent Liabilities: Issues and Practice. IMF Working Paper. WP/08/245. Washington, DC: International Monetary Fund (IMF).

Chilean Budget Department. 2007. Informe de Pasivos Contingentes 2007. Dirección de Presupuestos del Ministerio de Hacienda. Accessed at: https://www.dipres.gob.cl/598/articles-21701 doc pdf.pdf.

Colombian Ministry of Finance and Public Credit. 2015. Resolution 923 of 2015. Diario Oficial No. 49.482. 14 April. Accessed at: https://normativa.colpensiones.gov.co/colpens/docs/resolucion minhacienda_0932_2015.htm.

Dippelsman, R., C. Dziobek and C.A. Gutierrez Mangas. 2012. What Lies Beneath: The Statistical Definition of Public Sector Debt-An Overview of the Coverage of Public Sector Debt for 61 Countries. Staff Discussion Note SDN/12/09. Washington, DC: IMF.

Eichengreen, B. 1996. Financing Infrastructure in Developing Countries: Lessons from the Railway Age. In A. Mody (ed.), Infrastructure Delivery: Private Initiative and the Public Good. Washington, DC: World Bank. pp. 107-27.

European Commission, IMF, Organisation for Economic Co-operation and Development, United Nations, and World Bank. 2009. System of National Accounts 2008. New York.

Eurostat. 2019. Manual on Government Deficit and Debt: Implementation of ESA 2010-2019 Edition. Luxembourg: European Commission.

Ferrarini, B. and M. Hinojales. 2018. State-Owned Enterprises Leverage as a Contingency in Public Debt Sustainability Analysis: The Case of the People's Republic of China. ADB Economics Working Paper Series. No. 534. Manila: ADB.

Frame, W.S., A. Fuster, J. Tracy and J. Vickery. 2015. The Rescue of Fannie Mae and Freddie Mac. Journal of Economic Perspectives. 29(2), pp. 25-52.

Goolsbee, A.D. and A.B. Krueger. 2015. A Retrospective Look at Rescuing and Restructuring General Motors and Chrysler. Journal of Economic Perspectives. 29(2), pp. 3-24.

Government of Bhutan, Ministry of Finance. 2019. Annual Financial Statements of the Royal Government of Bhutan for the Year Ended 30 June 2018. Thimphu. Accessed at: https://www.mof .gov.bt/wp-content/uploads/2019/05/AFS2017-18English.pdf.

Government of India, Ministry of Finance. 2010. Government Guarantee Policy. New Delhi. Accessed at: https://dea.gov.in/sites/default/files/govern_guarantee_policy_1.pdf.

Government of India, Ministry of Finance. 2020a. Medium Term Fiscal Policy Cum Fiscal Policy Strategy Statement. Accessed at: https://www.indiabudget.gov.in/budget2020-21/doc/frbm2.pdf.

Government of India, Ministry of Finance. 2020b. Receipts Budget. Accessed at: https://www .indiabudget.gov.in/budget2020-21/doc/rec/allrec.pdf.

Government of the Philippines, Development Budget Coordination Committee. 2019. Fiscal Risks Statement 2019. Accessed at: https://www.dbm.gov.ph/wp-content/uploads/DBCC_MATTERS/ FiscalRiskStatement/FISCAL_RISKS_STATEMENT_2019.pdf.

Hemming, R., M. Alier, B. Anderson, M. Cangiano and M. Petrie. 2006. Public-Private Partnerships, Government Guarantees, and Fiscal Risk. Washington, DC: IMF.

International Monetary Fund (IMF). 2008. Fiscal Risks—Sources, Disclosure, Management. Washington, DC.

International Monetary Fund (IMF). 2011. Public Sector Debt Statistics: Guide for Compilers and Users. Washington, DC. pp. 47-51.

International Monetary Fund (IMF). 2014. Government Finance Statistics Manual 2014. Washington, DC.

International Monetary Fund (IMF). 2016. Analyzing and Managing Fiscal Risks-Best Practices. Washington, DC.

International Monetary Fund (IMF). 2017. How to Strengthen the Management of Government Guarantees. IMF How-To Note. No. 17/01. Washington, DC.

International Monetary Fund (IMF). 2020. Fiscal Monitor, April 2020. Washington, DC. Accessed at: https://www.imf.org/en/Publications/FM/Issues/2020/04/06/fiscal-monitor-april-2020. 
International Public Sector Accounting Standards (IPSAS) Board. 2018a. Handbook of International Public Sector Accounting Pronouncements. Volume I. New York: International Federation of Accountants. Accessed at: https:/www.ifac.org/system/files/publications/files/IPSASB-HandBook -2018-Volume-1.pdf.

International Public Sector Accounting Standards (IPSAS) Board. 2018b. Handbook of International Public Sector Accounting Pronouncements. 2018 edn. Volume II. New York: International Federation of Accountants. Accessed at: https://www.ifac.org/system/files/publications/files/IPSASB-HandBook -2018-Volume-2.pdf.

International Public Sector Accounting Standards (IPSAS) Board. 2018c. Handbook of International Public Sector Accounting Pronouncements. 2018 edn. Volume III. New York: International Federation of Accountants. Accessed at: https://www.ifac.org/system/files/publications/files/IPSASB-HandBook -2018-Volume-3.pdf.

Irwin, T.C. 2007. Government Guarantees: Allocating and Valuing Risk in Privately Financed Infrastructure Projects. Washington, DC: World Bank.

Irwin, T.C. 2015. Defining the Government's Debt and Deficit. Journal of Economic Surveys. 29(4), pp. 711-32.

Irwin, T.C. 2019. Not Taking Debt at Face Value, or Market Value or Amortized Cost: Policy Value as a Measure of the Burden of Public Debt. Financial Accountability and Management. 35(3), pp. 275-89.

Irwin, T., M. Klein, G.E. Perry and M. Thobani (eds) 1997. Dealing with Public Risk in Private Infrastructure. Washington, DC: World Bank.

Jaramillo, L., C. Mulas-Granados and E. Kimani. 2017. Debt Spikes and Stock Flow Adjustments: Emerging Economies in Perspective. Journal of Economics and Business. 94, pp. 1-14.

Kharas, H. and D. Mishra. 2001. Fiscal Policy, Hidden Deficits, and Currency Crises. In S. Devarajan, F. Halsey Rogers and L. Squire (eds), World Bank Economists' Forum. Washington, DC: World Bank. pp. 31-48.

Kopits, G. 2014. Coping with Fiscal Risk: Analysis and Practice. OECD Journal on Budgeting. 2014(1), pp. 47-71.

Lee, M. and K. Naqvi. 2020. State-Owned Enterprises in the People's Republic of China. In E. Ginting and K. Naqvi (eds), Reforms, Opportunities, and Challenges for State-Owned Enterprises. Manila: ADB. pp. 190-225.

Lucas, D. (ed.) 2010. Measuring and Managing Federal Financial Risk. National Bureau of Economic Research Conference Report. Chicago, IL: University of Chicago Press.

Lucas, D. and M. Phaup. 2008. Reforming Credit Reform. Public Budgeting \& Finance. 28(4), pp. $90-110$.

Mann, F.K. 1947. The Dual-Debt System as a Method of Financing Government Corporations. Journal of Political Economy. 55(1), pp. 39-56.

Mbaye, S., M. Moreno-Badia and K. Chae. 2018. Global Debt Database: Methodology and Sources. IMF Working Paper. WP/18/111. Washington, DC: IMF.

Merton, R.C. 1977. An Analytical Derivation of the Cost of Deposit Insurance and Loan Guarantees: An Application of Modern Option Pricing Theory. Journal of Banking and Finance. 1(1), pp. 3-11.

New South Wales Treasury. 2014. Government Guarantee Fee Policy for Government Businesses. Policy \& Guidelines Paper. TPP 14-03. Accessed at: https://www.treasury.nsw.gov.au/sites/default/files/ 2017-09/TPP14-03\%20\%20Government\%20Guarantee\%20Fee\%20Policy\%20for\%20Government $\% 20$ Businesses.pdf.

New Zealand Minister of Finance. 2001. Receiver Appointed for Terralink. Press release. Accessed at: https://www.beehive.govt.nz/release/receiver-appointed-terralink.

New Zealand Treasury. 2016. Response to FEC Questions on Solid Energy. Accessed at: https://treasury .govt.nz/sites/default/files/2013-06/se-3363387.pdf.

New Zealand Treasury. 2019. Financial Statements of the Government of New Zealand for the Year Ended 30 June 2019. Accessed at: https://www.treasury.govt.nz/publications/year-end/financial -statements-2019.

Peruvian Ministry of Economics and Finance. 2007. Metodología de Valuación de Pasivos Contingentes Cuantificables y del Flujo de Ingresos Derivados de la Explotación de los Proyectos Generados por la 
Suscripción de Contratos de Concesión Bajo la Modalidad de Asociación Público Privada (APP) en Perú. Dirección General de Asuntos Económicos y Sociales. August. Accessed at: https://www.mef .gob.pe/contenidos/pol_econ/documentos/Metodologia_Valuacion_Pasivos_Contingentes.pdf.

Phaup, M. 1985. Accounting for Federal Credit: A Better Way. Püblic Budgeting \& Finance. 5(3), pp. 29-39.

Phaup, M. 1993. Recent Federal Efforts to Measure and Control Risk-Bearing. In M.S. Sniderman (ed.), Government Risk-Bearing: Proceedings of a Conference Held at the Federal Reserve Bank of Cleveland, May 1991. Boston: Kluwer Academic Publishers. pp. 167-76.

Phaup, M. 2009. Federal Use of Implied Guarantees: Some Preliminary Lessons from the Current Financial Distress. Public Administration Review. 69, pp. 651-9.

Philippines Power Sector Assets \& Liabilities Management Corporation. 2020. Financial Statements for 2019. Accessed at: https://psalm.gov.ph/transparencyseal.

Polackova, H. 1998. Contingent Government Liabilities: A Hidden Risk for Fiscal Stability. Policy Research Working Paper. 1989. World Bank.

Schick, A. 2002. Budgeting for Fiscal Risk. In H.P. Brixi and A. Schick (eds), Government at Risk: Contingent Liabilities and Fiscal Risk. Washington, DC: World Bank and World Bank, pp. 79-97.

Thai Public Debt Management Office. 2020. Public Debt Status Summary as of June 30th, 2020. Accessed at: $\quad$ https://www.pdmo.go.th/pdmomedia/documents/2020/Jul/Public\%20Debt\%20Outstanding \%20Report\%20as\%20of\%20June\%2030th,\%202020.pdf.

Towe, C.M. 1991. The Budgetary Control and Fiscal Impact of Government Contingent Liabilities. IMF Staff Papers. 38(1), pp. 109-34.

UK Office for National Statistics. 2020. Public Sector Finances, UK: June 2020. Accessed at: https://www.ons.gov.uk/economy/governmentpublicsectorandtaxes/publicsectorfinance/bulletins/p ublicsectorfinances/june2020.

UK Treasury. 2019. Whole of Government Accounts: Year Ended 31 March 2018. London: HM Treasury. Accessed at: https://assets.publishing.service.gov.uk/government/uploads/system/uploads/ attachment data/file/803753/WGA_2017-18_PRINT_1.pdf.

World Bank. 2013. Debt Management Performance Assessment (DeMPA): Armenia. Report 91014. Washington, DC.

World Bank. 2019. Assessing and Managing Credit Risk from Contingent Liabilities: A Focus on Government Guarantees. Debt Management Learning \& Training Notes. 2. Washington, DC: World Bank Treasury. 